\title{
Factors Influencing the Implementation of Management Accounting Systems in Small and Medium Sized Enterprises in Dubai
}

\author{
Omar Albaddad $^{1}$, Mahmoud Nassar ${ }^{2}$ \\ ${ }^{1}$ Head of Accounting Department Private Company, Dubai \\ ${ }^{2}$ Associate professor, Applied Science Private University, Jordan \\ Correspondence: Mahmoud Nassar, Associate professor, Applied Science Private University, Jordan.
}

Received: November 15, 2017

Accepted: December 15, 2017

Online Published: December 27, 2017

doi:10.5539/ibr.v11n1p245

URL: https://doi.org/10.5539/ibr.v11n1p245

\begin{abstract}
The aim of this study is to examine whether each of the variables (level of competition, age of enterprise, type of sector, quality of ownership, and size of enterprise) has an impact on adopting administrative accounting practices measured by each of (cost systems, budget systems, performance assessment systems) within small and middle sized industrial enterprises in Dubai, in addition to determining whether enterprises are facing difficulties in applying administrative accounting practices. The population of the study represents all small and middle sized industrial enterprises in Dubai. To achieve the study objectives, a questionnaire is designed and distributed on the study sample which consists of (160) accountants and financial mangers working at small and middle sized enterprises in Dubai. The researcher could retrieve (127) responses and (32) responses have been disregarded; thus, the final study sample is represented by (95) responses. For the purpose of the study, the analytical descriptive approach is also employed. Furthermore, to test the study hypothesis, multiple regression model and One Sample T- test are used. The study findings re veal that small and middle sized enterprises in Dubai apply all administrative accounting practices represented by each of (cost systems, budget systems, performance assessment systems). As well, there is an impact of each of the variables (level of competition, age of enterprise, type of sector, quality of ownership, and size of enterprise) on adopting administrative accounting practices measured by each of (cost systems, budget systems, performance assessment systems). Moreover, the study finds that small and middle sized industrial enterprises in Dubai face difficulties in adopting administrative accounting practices but in a slight degree in which that the arithmetical average value is very close to the default average value.
\end{abstract}

Keywords: implementation of management accounting systems, small and medium - size enterprises, Dubai

\section{Introduction}

Dubai is considered one of the fastest growing regions in the world in terms of economic growth and trade. The small and medium sized enterprises are the backbone of Dubai's economy, as they account for $95 \%$ of the United Arab Emirates listed businesses. These enterprises are responsible for employing $42 \%$ of the workforce and furthermore contribute to $40 \%$ of Dubai's economy. The government in Dubai focuses heavily on enhancing the contribution and performance of the SME's sector in order view them as equals in theory to develop and high-income countries (State Report of SME's in Dubai for 2013).

The study problem shows that the value and importance of administrative accounting is the most important component of information systems from one aspect. From another aspect the nature and importance of small and medium sized enterprises presence in any country, especially the industrial side due to the importance of the element of calculating product cost and taking the most important managerial decisions. The fact that enterprises do not use the management accounting methods to provide appropriate information to the management leads to weakness and less competitiveness at the global level, and even at local level. Therefore, the company must apply management accounting methods and de velop them to enable the company management to make decisions based on scientific grounds.

Accordingly, the study was conducted to identify the extent needed for the use of management accounting practices in small and medium sized industrial enterprises in Dubai and the factors influencing the use of such practices. To the knowledge of the researcher no previous study has targeted the use of management accounting practices in small and medium industrial enterprises in Dubai. The study problem can be formulated by the 
following questions:

The research problem can be precisely framed by the following sub-questions:

1- Do any of the variables listed (degree of competition, age of establishment, type of sector, quality of ownership and the size of the enterprise) affect the adoption of management accounting practices (measured by cost systems) in small and medium sized industrial enterprises in Dubai?

2- Do any of the variables listed (degree of competition, age of establishment, type of sector, quality of ownership and size of the enterprise) affect the adoption of management accounting practices (measured by budget systems) in small and medium sized industrial enterprises in Dubai?

3- Do any of the variables listed (degree of competition, age of establishment, type of sector, quality of ownership and the size of enterprise) affect the adoption of management accounting practices (measured by performance evaluation systems) in small and medium sized industrial enterprises in Dubai?

\section{Conceptual Framework}

\subsection{Small and Medium Sized Industrial Enterprises in Dubai}

According to the official definition issued by the Mohammed Bin Rashid Establishment for the Development of Small and Medium Enterprises of the Department of Economics Development for Dubai in 2013, SME's are: any establishment that carries out legal economic activity and is commercially registered (Dubai Economic Zone) or a free zone authority or industrial zone. In which abides by the criteria for the number of workers and total returns, according to the sector to which it belongs (trade/industry/services). Furthermore, according to the above definition, the industrial establishments for the purposes of this study were classified as shownin Table 1 as follows.

Table 1. classification of SMEs in Dubai

\begin{tabular}{lll}
\hline Type of Ente rprise & No. of workers & Total Returns \\
\hline Very Small & Less than 20 & More than 1 million Derhams and less than 100 million Derhams \\
Small & Less than 100 & More than 100 million Derhams and less than 250 million Derhams \\
Medium & Less than 250 & More than 250 million Derhams \\
\hline 2.2 Previous Studies & &
\end{tabular}

The first study reviewed in this section is the study of Adler et al, (2000), which aimed to measure the extent to which firms use advanced management accounting practices and the methods of comparison with traditional methods on a sample of 165 industrial companies in New Zealand. The conclusion of the study was that most companies use many modern methods while not abandoning the use of traditional management accounting methods. The study also concluded that the most important obstacles in adopting modern methods were due to the determinants and limitans of human resources in these companies.

The study of Hamdallah, Shaban and Srouji (2014) aimed to explore the describe the use of cost accounting in textile, leather and garment companies in Jordan in terms of material cost, labour cost and indirect costs. The study also reviewed the impact of the use of cost systems on the pricing process using the distribution of a questionnaire to 76 participants. The study found that these companies suffer from a very high le vel of efficiency in which forces them to use cost systems to price their products, whilst considering material, labour and indirect costs. The study indicates that good quality, efficient systems, cost accounting and new technologies could and should be adopted, developed and implemented throughout the organisation, such as $\mathrm{ABC}$ and target costs. Furthermore, companies should also hire qualified cost accountants or train their own employees to use these systems. In addition, it is strongly suggested that further studies should be done about textiles, leather and garment companies to highlight the systems of management accounting. The results showed a relationship between the cost accounting system and the pricing process in small textile, leather and garment companies in Jordan with respect to independent variables.

Furthermore, Ozyurek \& Yilmaz (2015) conducted a study titled "The Application of cost systems in small and medium sized enterprises in Turkey". The objective of the study was to describe and explain the adoption and application of cost systems in small and medium enterprises in Turkey. The researchers conducted a survey during 2014 on small and medium enterprises in Ankara, the results were evaluated using the SPSS system. The results of the study showed that the measuring operations and the similar production lines are more accurate than conventional cost systems. However, direct costs and public expenditures in return reduce the burden of increasingly sophisticated production facilities. This leads researchers to seek the cost of traditional systems of alternative technologies. 


\section{Population and Study Sample}

The study population consists of all the small and medium sized industrial enterprises in the Emirate of Dubai, based on the report of the 307 companies issued by the Department of Economic Development in Dubai in 2014. This report is considered to be the latest report approved by Dubai in the classification of small and medium sized industrial enterprises. The researchers distributed 160 questionnaires to the accountants and financial managers in the small and medium sized industrial enterprises in Dubai as the study sample. The researchers could retrieve 127 answered responses, 32 questionnaires were excluded due to the lack of seriousness when answering, and therefore the final study sample was 95 .

\section{Descriptive Statistics of the Study Sample and Variables}

Table 2 shows the demographic distribution of the study sample, it is clear from the table that most of the sample members hold a bachelor's degree of higher which was represented by $91.6 \%$ of the study sample. However, regarding the career level in the accounting profession, it is noted that the study sample took into consideration the managers, deputy managers and head of accounting and cost departments, furthermore it is noticed that most of the study sample contained were head of accounting departments with a percentage of $43.2 \%$. Finally, regarding the years of experience in accounting, most of the study sample has sufficient experience. As the percentage of those who have 5 or more years of experience was $81.1 \%$, this led to increased stability in the questionnaire as explained previously.

Table 2. Demographic Distribution of the Study Sample

\begin{tabular}{lcc}
\hline Item & Repeat & Percentage \\
\hline Education Qualification; & 8 & $8.4 \%$ \\
Diploma & 67 & $70.5 \%$ \\
Bachelors & 15 & $15.8 \%$ \\
Masters & 5 & $5.3 \%$ \\
PhD & & \\
Career Le vel in Accounting Profession; & 7 & $7.4 \%$ \\
Manager & 12 & $12.6 \%$ \\
Deputy Manager & 41 & $43.2 \%$ \\
Head of Accounting Department & 35 & $36.8 \%$ \\
Head of Cost Department & & $18.9 \%$ \\
Years of Experience in Accounting Profession; & 18 & $67.4 \%$ \\
From 1 year - less than 5 years & 64 & $13.7 \%$ \\
From 5 years - less than 10 years & 13 & $\mathbf{1 0 0 \%}$ \\
10 years or more & $\mathbf{9 5}$ & \\
Total & & \\
\hline
\end{tabular}

Table 3 presents the descriptive analysis of the answers to the independent variable which are (size, degree of competition, age of enterprise, type of sector and type of ownership). The table shows that most of the enterprises in the sample have an annual sales volume of more than 250 million dirhams, this is due to the large capital in which drives the economy of the United Arab Emirates in general and the Emirate of Dubai specifically. Many of the enterprises in the sample are aged between $9-12$ years. In addition, nearly $50 \%$ of the sample companies belong to the UAE and 50\% are of shared ownership. The researcher believes that the reason is due to the large volume of foreign investments in the Emirate of Dubai in comparison to other countries in the Arab world. Furthermore, as for the types of major industrial sectors, the distribution of the sample of the study on many major industrial sectors $10.5 \%$, the manufacture of beverages and food $28.4 \%$, and the wood processing manufacturing sector $24.2 \%$. In terms of competition, there is competition between the sample companies on the main product line in the Emirate of Dubai where 80\% of the companies had the size of the competition between the strong and the very strong scale, similarly the size of competition on the main product lines of companies outside the UAE with $88.4 \%$ of the companies have competition between the strong and very strong scale. 
Table 3. the descriptive analysis of the answers to the independent variable

\begin{tabular}{|c|c|c|}
\hline Item & Repeat & Percentage \\
\hline \multicolumn{3}{|l|}{ What is your annual sales volume? } \\
\hline Less than 10 million Dirhams & 0 & $0 \%$ \\
\hline $\begin{array}{l}\text { More than } 10 \text { million Dirhams and less } \\
\text { than } 100 \text { million Dirham }\end{array}$ & 0 & $0 \%$ \\
\hline $\begin{array}{l}\text { More than } 100 \text { million Dirhams and less } \\
\text { than } 150 \text { million Dirhams }\end{array}$ & 12 & $12.6 \%$ \\
\hline $\begin{array}{l}\text { More than } 150 \text { million Dirhams and less } \\
\text { than } 250 \text { million Dirhams }\end{array}$ & 21 & $22.1 \%$ \\
\hline More than 250 million Dirhams & 62 & $65.3 \%$ \\
\hline \multicolumn{3}{|l|}{ Age of Current Company } \\
\hline From 1 year to less than 3 years & 0 & $0 \%$ \\
\hline 3 years or more and less than 7 years & 10 & $10.5 \%$ \\
\hline 7 years or more and less than 9 years & 14 & $14.7 \%$ \\
\hline 9 years or more and less than 12 years & 41 & $43.2 \%$ \\
\hline More than 12 years & 30 & $31.6 \%$ \\
\hline \multicolumn{3}{|l|}{ Type of Ownership of Company } \\
\hline Emirates & 47 & $49.5 \%$ \\
\hline Mixed Ownership & 48 & $50.5 \%$ \\
\hline \multicolumn{3}{|c|}{ Under which Main Indus trial Sector is your Company's business nature } \\
\hline Clothes Manufacture & 10 & $10.5 \%$ \\
\hline Metal Products Manufacture & 13 & $13.7 \%$ \\
\hline Basic Metal Manufacture & 10 & $10.5 \%$ \\
\hline Beverages \& Food Manufacture & 27 & $28.4 \%$ \\
\hline Wood Product Manufacture & 23 & $24.2 \%$ \\
\hline Other & 12 & $12.6 \%$ \\
\hline \multicolumn{3}{|c|}{ What is the Size of Competition on the company's main product lines in Dubai } \\
\hline Very weak & 0 & $0 \%$ \\
\hline Weak & 6 & $6.3 \%$ \\
\hline Medium & 13 & $13.7 \%$ \\
\hline Strong & 51 & $53.7 \%$ \\
\hline Very Strong & 25 & $26.3 \%$ \\
\hline \multicolumn{3}{|c|}{ What is the Size of Competition on the company's main product lines outside the Emirates } \\
\hline Very Weak & 0 & $0 \%$ \\
\hline Weak & 2 & $2.1 \%$ \\
\hline Medium & 9 & $9.5 \%$ \\
\hline Strong & 47 & $49.5 \%$ \\
\hline Very Strong & 37 & $38.9 \%$ \\
\hline Total & 95 & $100 \%$ \\
\hline
\end{tabular}

Table 4 presents the descriptive analysis of the answers to the questions of the first variable (cost systems). The table above shows that most cost systems applied in accordance to the study sample are those cost systems related to the production stage which had an average of 4.47 and in accordance to the five-point Likert scale this result is "extremely highly applied". It is also noted that there is a good level of application of order stage systems which had an average of 4.25 with a result of "highly applied". There is a good level of application of the activity based cost systems in the study sample with average of 3.47 and result of "highly applied". It is shown that all companies from the study sample apply the cost systems.

Table 4. The Descriptive Analysis of the questions for the first dependent variable

\begin{tabular}{lccl}
\hline Cost System & Mean & S-Deviation & Result \\
\hline Cost of Production Order System & 4.25 & 1.10 & Highly Applied \\
Cost of Production Stage System & 4.47 & 0.35 & Highly Applied \\
Variable Cost System & 3.81 & 1.09 & Highly Applied \\
Total Cost System & 4.14 & 0.69 & Highly Applied \\
Activity Based Costing System & 3.47 & 0.62 & $\begin{array}{l}\text { Extremely } \\
\text { Applied }\end{array}$ \\
Total Axis Result & & & Highly Applied \\
\hline \multicolumn{2}{l}{} \\
\hline
\end{tabular}

Table 5 presents the descriptive analysis of the answers to the questions of the second dependent variables (budget systems). It is clear from the table that the lowest item to be applied according to the average the "zero estimated budget" with an average of 3.74. The highest item to be applied was the item "cash flow estimates" where the average was 4.47 with the result of "extremely highly applied". The full axis results averaged with a total of 4.02, according to the five-point Likert scale and the result of the axis is "highly applied". These results explain the level of application of performance appraisal systems in the study sample companies, it is also 
noticed from the table that all companies in the study sample apply performance appraisal systems.

Table 5. The Descriptive Analysis of the questions for the second dependent variable

\begin{tabular}{lccl}
\hline Budget Systems & Mean & S-Deviation & \multicolumn{1}{c}{ Result } \\
\hline Estimated Budget Sales & 4.25 & 0.71 & Extremely Highly Applied \\
Estimated Budget Purchases & 4.06 & 1.10 & Highly Applied \\
Estimated Budget Production & 3.75 & 0.44 & Highly Applied \\
Cash Flow Estimates & 4.47 & 0.62 & Extremely Highly Applied \\
Estimated Budget for financial position of & 4.14 & 0.69 & Highly Applied \\
company & & & \\
Flexible Budgets & 3.81 & 1.09 & Highly Applied \\
Comprehensive Budgets & 4.14 & 0.69 & Highly Applied \\
Zero Estimated Budgets & 3.74 & 0.44 & Highly Applied \\
Activity Based Cost Estimated Budget & 3.11 & 1.09 & Neutral \\
Full Axis Result & $\mathbf{4 . 0 2}$ & $\mathbf{0 . 4 6}$ & Highly Applied \\
\hline
\end{tabular}

Percentage of companies that apply budget systems $=100 \%$

Table 6 shows the descriptive analysis of the responses to the questions of the third variable (performance appraisal systems). It is noticed from the table that the most effective performance appraisal system for small and medium sized industrial enterprises in Dubai are the number of complaints by customers variable which had an average of 4.47 and in accordance to five-point Likert scale this is considered "extremely highly applied". Whereas the "market share" and "delivery on time" both averaged with 3.74 with a result of "extremely highly applied". It is also noted that there is a good application of performance appraisal systems in general in the companies of the study sample with an average of 3.99 with a result of "highly applied", it is also noted that all the companies in the study sample apply performance appraisal system.

Table 6. The Descriptive Analysis of the questions for the third dependent variable

\begin{tabular}{|c|c|c|c|}
\hline Performance Appraisal Systems & Mean & S-Deviation & Result \\
\hline Operating Income & 4.25 & 0.71 & Extremely Highly Applied \\
\hline Analysis of Variance & 3.75 & 0.44 & Highly Applied \\
\hline Market Share & 3.74 & 0.44 & Highly Applied \\
\hline No. of customer complaints & 4.14 & 0.69 & Highly Applied \\
\hline Customer Satisfaction & 3.81 & 1.09 & Highly Applied \\
\hline Delivery on Time & 3.74 & 0.44 & Highly Applied \\
\hline Manufacturing Cycle Duration & 3.81 & 1.09 & Highly Applied \\
\hline Damage Rate & 4.26 & 0.44 & Extremely Highly Applied \\
\hline Staff Turnover & 3.75 & 0.44 & Highly Applied \\
\hline Full Axis Result & 3.99 & 0.41 & Extremely Highly Applied \\
\hline
\end{tabular}

\section{Testing the Study Hypotheses}

To test the three main hypotheses, the researcher subjected the study data to analysis using the multiple regression method. Based on the analysis, the results are presented in the following table:

Table 7. Multiple Regression Test Results for the First Main Hypothesis



Where Y1 refers to the dependent variable of managerial accounting practices represented by cost systems, XI refers to the degree of competition as an independent variable, X2 refers to the age of the establishment as an independent variable, $X 3$ refers to the type of sector as an independent variable, $X 4$ refers to the type of ownership as an independent variable, $X 5$ refers to the size of the enterprise as an independent variable.

From reading the results shown in table 8 above regarding the test of the study hypothesis, we can see that: 
Firstly: In the case of the first main hypothesis (Ho1) which states "the variables (degree of competition, age of enterprise, type of sector, type of ownership and the size of the enterprise) do NOT affect the process of adopting managerial accounting practices (measured by cost systems) in Dubai". This is further explained by:

1. Where Sig F is 0.000 , it is below the significant level required which is 0.05 . Therefore, the first null hypothesis $\mathrm{Ho} 1$ is rejected and the alternative hypothesis $\mathrm{H} \alpha$ is accepted. This means that each of the study variables will affect the adoption of managerial accounting systems (measured by cost systems) in small and medium sized industrial enterprises in Dubai.

2. The value of the Correlation Coefficient $\mathrm{R}$ was 0.819 , this confirms that there is a positive and high relationship between the variables (degree of competition, age of establishment, quality of property and size of establishment) and the process of adopting accounting practices related to cost systems. The value of $R^{2}(0.653)$ means that approximately $65.3 \%$ of the fluctuations in managerial accounting practices are from cost systems and can be explained by the changes that occur to the variables (degree of competition, age of establishment, quality of property and size of establishment) and excluding the type of sector. In addition, the relatively low value of the coefficient of selection indicates that there are possibly other external factors causing a reciprocal effect.

Table 9. Multiple Regression Test Results for the Second Main Hypothesis

\begin{tabular}{|c|c|c|c|c|}
\hline Model & B & $\begin{array}{l}\text { Standardized } \\
\text { Coefficients }\end{array}$ & $\mathbf{T}$ & Sig \\
\hline Constant & 1.306 & $-\cdots$ & 5.307 & 0.000 \\
\hline X1 & 0.248 & 0.285 & 3.785 & 0.000 \\
\hline X2 & 0.188 & 0.386 & 4.757 & 0.000 \\
\hline X3 & -0.016 & -0.053 & -0.907 & 0.367 \\
\hline X4 & 0.123 & 0.134 & 2.252 & 0.027 \\
\hline X5 & 0.181 & 0.280 & 3.664 & 0.000 \\
\hline \multicolumn{2}{|c|}{$\begin{array}{r}\text { F test Model }=42.079 \\
\text { Adjusted R Square }=\mathbf{0 . 6 8 6} \\
\text { F Dis tribution Table }=4.147 \\
\text { Y2 }=\beta 0+\beta 1\end{array}$} & $3+\beta 4 * \mathbf{X}^{\mathrm{T}}$ & $\begin{array}{l}\mathrm{F}=0.0 \\
=0.838 \\
\text { on Tab }\end{array}$ & \\
\hline
\end{tabular}

Where $Y 2$ refers to the dependent variable of managerial accounting practices represented by budget systems, XI refers to the degree of competition as an independent variable, X2 refers to the age of the establishment as an independent variable, $X 3$ refers to the type of sector as an independent variable, X4 refers to the type of ownership as an independent variable, $X 5$ refers to the size of the enterprise as an independent variable.

From reading the results shown in table 9 above regarding the test of the study hypothesis, we can see that:

Firstly: In the case of the second main hypothesis Ho2 which states 'the variables (degree of competition, age of enterprise, type of sector, type of ownership and the size of the enterprise) do NOT affect the process of adopting managerial accounting practices (measured by budget systems) in Dubai". This is further explained by:

1. Where Sig F is 0.000 , it is below the significant level required which is 0.05 . Therefore, the second null hypothesis $\mathrm{Ho} 2$ is rejected and the alternative hypothesis $\mathrm{H} \alpha$ is accepted. This means that each of the study variables will affect the adoption of managerial accounting systems (measured by budget systems) in small and medium sized industrial enterprises in Dubai.

2. The value of the Correlation Coefficient $\mathrm{R}$ was 0.838 , this confirms that there is a positive and high relationship between the variables (degree of competition, age of establishment, quality of property and size of establishment) and the process of adopting accounting practices related to budget systems. The value of $R^{2}(0.686)$ means that approximately $68.6 \%$ of the fluctuations in managerial accounting practices are from cost systems and can be explained by the changes that occur to the variables (degree of competition, age of establishment, quality of property and size of establishment) and excluding the type of sector. In addition, the relatively low value of the coefficient of selection indicates that there are possibly other external factors causing a reciprocal effect. 
Table 10. Multiple Regression Test Results for the Third Main Hypothesis

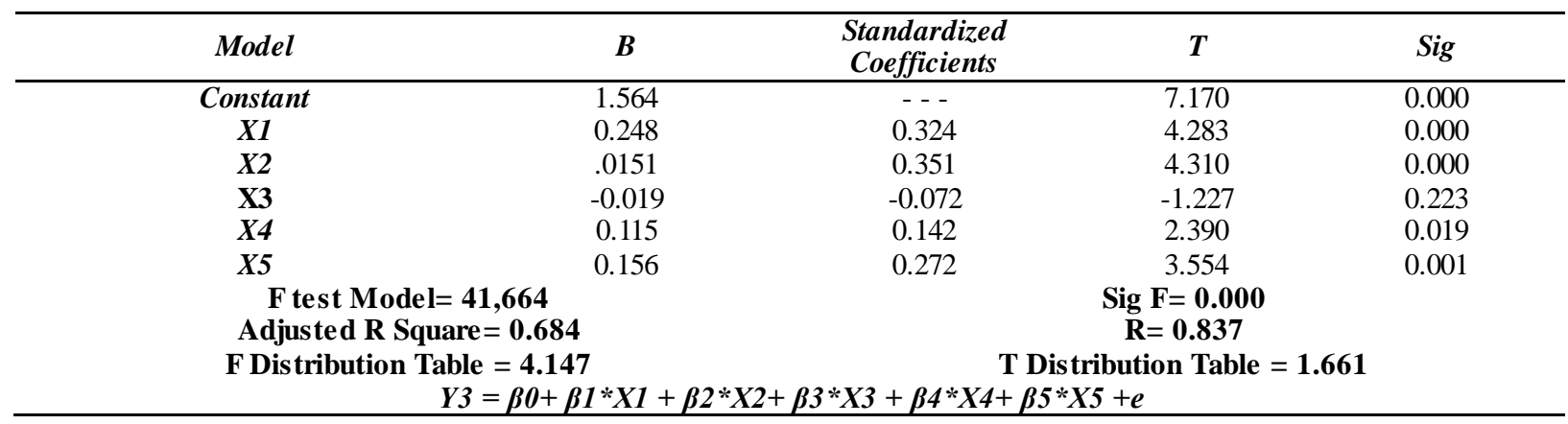

Where Y3 refers to the dependent variable of managerial accounting practices represented by performance appraisal systems, $X 1$ refers to the degree of competition as an independent variable, $X 2$ refers to the age of the establishment as an independent variable, $X 3$ refers to the type of sector as an independent variable, $X 4$ refers to the type of ownership as an independent variable, X5 refers to the size of the enterprise as an independent variable.

From reading the results shown in table 10 above regarding the test of the study hypothesis, we can see that:

Firstly: In the case of the third main hypothesis Ho3 which states "the variables (degree of competition, age of enterprise, type of sector, type of ownership and the size of the enterprise) do NOT affect the process of adopting managerial accounting practices (measured by performance appraisal systems) in Dubai". This is further explained by:

1. Where Sig F is 0.000 , it is below the significant level required which is 0.05 . Therefore, the third null hypothesis $\mathrm{Ho} 3$ is rejected and the alternative hypothesis $\mathrm{H} \alpha$ is accepted. This means that each of the study variables will affect the adoption of managerial accounting systems (measured by performance appraisal systems) in small and medium sized industrial enterprises in Dubai.

2. The value of the Correlation Coefficient $\mathrm{R}$ was 0.837 , this confirms that there is a positive and high relationship between the variables (degree of competition, age of establishment, quality of property and size of establishment) and the process of adopting accounting practices related to performance appraisal systems. The value of $R^{2}(0.684)$ means that approximately $68.4 \%$ of the fluctuations in managerial accounting practices are from cost systems and can be explained by the changes that occur to the variables (degree of competition, age of establishment, quality of property and size of establishment) and excluding the type of sector. In addition, the relatively low value of the coefficient of selection indicates that there are possibly other external factors causing a reciprocal effect.

\section{Results}

Firstly, based on statistical tests and the test hypotheses, the results can be summarized in the following: small and medium sized enterprises in Dubai in general apply all management accounting practices represented by cost, budget and performance appraisal systems. The researcher believes that the reason behind this is that Dubai is not considered a developing country, this in turn makes small and medium sized enterprises bear the development and technology as much as large companies in other countries, this explains its application to management accounting practices. As the variables (degree of competition, age of establishment, type of sector, type of ownership and size of the enterprise) all jointly lead towards the adoption of management accounting practices (measured by cost systems) in small and medium sized industrial enterprises in Dubai. On the individual level, there is an effect produced by all variables except for the type of sector variable on the adoption of management accounting practices (measured by cost systems) in small and medium sized industrial enterprises in Dubai. The researcher believes that this is caused by the increased degree in competition, therefore management is interested in reducing the cost of products whilst maintaining a high-quality product thus directed to applying cost systems. Furthermore, the longer the age of the establishment the more wise and rational is the management, which in turn positively affects the application of management accounting practices through cost systems. As for the type of sector, all industrial sectors are very similar in their operating systems because they are industrial; this therefore explains why there is no impact of the type of sector on the application of cost system.

Secondly, the results of the analysis also showed that the variables (degree of competition, age of establishment, type of sector, type of ownership and the size of the enterprise) combined to adopt management accounting practices (measure by budget systems) in small and medium sized industrial enterprises in Dubai. Finally, all 
variables (degree of competition, age of establishment, type of sector, type of ownership and the size of the enterprise) combine to adopt management accounting practices (measured by performance appraisal systems) in small and medium sized industrial enterprises. On the individual level, there is an effect caused by all variables on the adoption of management accounting practices (measured by performance appraisal systems) except from the type of sector variable in small and medium sized industrial enterprises in Dubai.

\section{References}

Adler, R., Everett, A., \& Waldron, M. (2000), Advanced Management Techniques in Manufacturing Utilization, Benefits and Barriers to Implementation. Accounting Forum, 131-150. https://doi.org/10.1111/1467-6303.00032

AlAdham, M., Alaffo, A., Abukhadijeh, M. A., \& Qasem, M. F. (2016). Tax Evasion and Tax Awareness Evidence from Jordan. International Business Research, 9(12), 65-75. https://doi.org/10.5539/ibr.v9n12p65

Alam, M. (2006). A comparative study of financing small and cottage industries by interest - free banks in Turkey, Cyprus, Sudan and Bangladesh. Humanomics, 24(2), 145-161. https://doi.org/10.1108/08288660810876859

Bagozzi, R., \& Yi, Y. (1988). On the evaluation of structural equation models. Journal of the academy of marketing science, 16, 74-94. https://doi.org/10.1007/BF02723327

Bayoud, N., Kavanagh, M., \& Slaughter, G. (2012). Factors influencing levels of corpor ate social responsibility disclosure by Libyan firms: A mixed study. International Journal of Economics and Finance, 4(4), 13-29. https://doi.org/10.5539/ijef.v4n4p13

Greenbank, P., (2000). Training micro business owner-managers: a challenge to current approach. Journal of European Industrial Training, 24(7), 403-411. https://doi.org/10.1108/03090590010377781

Hamdallah, M. E,, Osama, S. S., \& Srouji, A. F. (2014), Using Costing Systems in order to Price Products in Small Textile, Leather, and Clothing Companies. International Review of Management and Business Research, 3(1).

Hamide, Ö., \& Metin, Y. (2015). Application of Costing System in the Small and Medium Sized Enterprises (SME) in Turkey. International Journal of Social, Behavioral, Educational, Economic, Business and Industrial Engineering, 9(1)

Hayduk, L. (1987). Structural equation modeling with LISREL. Johns Hopkings University Press.

Hossain, M. (2008). The extent of disclosure in annual reports of banking companies: The case of India. European Journal of Scientific Research, 23(4), 660-681.

Hu, L., \& Bentler, P. (1999). Cutoff criteria for fit indexes in covariance structure analysis: Conventional criteria versus new alternatives. Structural Equation Modeling: A Multidisciplinary Journal, 6(1), 1-55. https://doi.org/10.1080/10705519909540118

Hussainey, K., Elsayed, M., \& Razik, M. A. (2011). Factors affecting corporate social responsibility disclosure in Egypt. Corporate Ownership and Control journal. https://doi.org/10.22495/cocv8i4c4art5

Kaplan, R., \&Atkinson, A. (1998). Advanced Management Accounting, 3ed, Prentice-hall. Inc, New Jersey.

Kelliher, R. (1984). The Evaluation of Management Accounting. The Accounting Review ‘July ،396.

Kelliher, R., \& Rein1, L. (2009). A resource-based view of micro-firm management practice. Journal of Small Business and Enterprise Development, 13(3), 521-532. https://doi.org/10.1108/14626000910977206

Mown, M., \& Hansen, D. (2006) Management Accounting the Cornerstone for Business Decision, Thomoson South-western, USA.

Qasem, M. F., Abukhadijeh, M. A., \& AlAdham, M. A. (2016). Customer Relationship Management and Customer Retention in Jordanian Bank. International Business Research, 9(9). https://doi.org/10.5539/ibr.v9n9p41

Report of SME's in Dubai for 2013.

\section{Copyrights}

Copyright for this article is retained by the author(s), with first publication rights granted to the journal.

This is an open-access article distributed under the terms and conditions of the Creative Commons Attribution license (http://creativecommons.org/licenses/by/4.0/). 